\title{
DE WIJZE VAN ONDERTEKENING \\ VAN DE ACCOUNTANTSVERKLARING
}

\author{
door Drs. J. Vogel
}

In het nummer van februari 1961 van dit maandblad komt een artikel voor van Prof. A. M. van Rietschoten over de ondertekening van de accountantsverklaring in het geval meerdere accountants onder een gemeenschappelijke naam optreden.

Er zijn twee wijzen van ondertekening van de verklaring te onderkennen, die ik ter voorkoming van veelvuldige herhaling der omschrijving zal aanduiden met $a$ en $b$ en daarbij de in ons land meest voorkomende wijze vooropstellen.

a. Onder de gemeenschappelijke naam wordt getekend met de persoonlijke naam van degeen, die de handtekening stelt.

b. Er wordt uitsluitend met de gemeenschappelijke naam getekend.

Van Rietschoten spreekt zijn voorkeur uit voor b en wel omdat dan zowel tegelijkertijd als in verschillende tijden de ondertekening van de van het kantoor uitgaande verklaringen eensluidend is, waardoor de vaktechnische eenheid van het kantoor het best naar buiten wordt gebracht.

$\mathrm{Bij}$ toepassing van a daarentegen kan de persoonlijke handtekening wisselen, terwijl aan het verschil in de ondertekening door de lezer van de verklaring geen enkele waarde behoort te worden toegekend.

Wanneer wij aan het wieden zijn in de tuin van onze vaktechnische verantwoordelijkheid moeten wij, meen ik, beseffen, dat die tuin een deelgebiedje is van de wereld daaromheen en waar Van Rietschoten stelt dat de wisseling in de persoonlijke ondertekening iedere betekenis mist zou ik willen opmerken dat dit dan al waar moge zijn voor het aspect van de vaktechnische verantwoordelijkheid doch dat die wisseling in ander opzicht wel iets heeft te zeggen. Er blijkt namelijk uit, dat de verklaring door een andere vennoot werd gegeven en dat zal doorgaans wel betekenen, dat ook die ander de leider van het onderzoek is geweest. Juist omdat dit de vaktechnische verantwoordelijkheid en de vaktechnische eenheid van het kantoor onaangetast laat is er naar mijn gevoelen niet het minste bezwaar tegen daar rond voor uit te komen.

Het is waarlijk bekend genoeg dat er mutaties in de vennoten voorkomen. De kantoren plegen daarvan aan relaties en collega's kennis te geven. Uit briefhoofd en uit de door de vereniging uitgegeven lijst van leden en kantoren kan dit worden afgeleid.

Dat door het publiek aan het wisselen van tekenende functionarissen betekenis zou worden gehecht ten aanzien van de vaktechnische eenheid van het kantoor valt nergens uit af te leiden en ik betwijfel dan ook of $b$ inderdaad een betere demonstratie van de vaktechnische eenheid oplevert dan a. Een duidelijke aanwijzing daarvoor heb ik in het artikel van Van Rietschoten niet kunnen vinden.

Ik ken wel enige redenen, niet door Van Rietschoten genoemd, die de in Nederland gebleken voorkeur voor a rechtvaardigen en gaarne geef ik gevolg aan de uitnodiging van de schrijver deze redenen in de gedachtenwisseling naar voren te brengen. Ze zijn:

1. De persoonlijke handtekening is de enige ware handtekening.

2. De wellevendheid brengt mede, dat men in het openbaar tredend zich bekend maakt. 
Ter toelichting op deze redenen, waarvan, naar ik meen, vooral de eerste zeer zwaar weegt, merk ik het volgende op.

Degeen, die met de gemeenschappelijke naam tekent, is niet de drager van de naam (c.q. de namen) waarmede hij tekent, doch heeft slechts de bevoegdheid die naam te gebruiken. Deze situatie kan niet beter tot uitdrukking worden gebracht dan door onder de gemeenschappelijke naam met de eigen naam te tekenen. Dit geeft naar algemeen aanvaarde normen nauwkeurig de situatie weer zoals deze is.

Hier vinden wij ook de verklaring voor het feit, dat niet getekend kan worden met een naam waarin ,accountantskantoor" voorkomt. Zo'n naam kan niet als ondertekening worden gebruikt om de eenvoudige reden dat een kantoor nu eenmaal niet kan tekenen. De onwaarheid zou dan te duidelijk in het oog springen. Ik meen dan ook, dat er een zeker gevaar in schuilt wanneer men het gebruik van zo'n naam zou afraden alleen omdat daarmede niet getekend kan worden. Dat lijkt mij de zaak op zijn kop zetten.

Door het duidelijke contrast met de waarheid ontstaan ook de bezwaren, die Van Rietschoten ziet opdoemen, indien zonder meer met één enkele eigennaam van een ander zou worden getekend.

Het behoeft geen verwondering te wekken, dat in een land waar de waarachtigheid $z$ waarder telt dan de traditie $b$ weinig ingang heeft gevonden.

De eventuele tegenwerping dat bij toepassing van b de gemeenschappelijke naam wordt geschreven op de eigen hem kenmerkende manier van de ondertekenaar en dus als zijn persoonlijke handtekening mag worden gezien, wijs ik bij voorbaat af. Bij overname in gedrukte stukken immers valt het kenmerk weg en als het daarin zou kunnen worden gehandhaafd dan is de discussie overbodig geworden omdat dan weer het geval optreedt, waarin verschillen in de ondertekening ontstaan, verschillen, die men niet kan opheffen door op de eensluidendheid te wijzen.

Mijn tweede reden is gelegen in de wellevendheid. Ik acht het korrekt, dat indien met een verklaring in de openbaarheid wordt getreden aan de lezer de weg wordt gewezen voor het geval hij over de verklaring met de accountant zou willen spreken. Eveneens in het raam van de wellevendheid kan de vraag worden gesteld of het klachtrecht van belanghebbenden moet worden bemoeilijkt door niet de naam van de tekenende functionaris te vermelden.

Ik meen, dat de problematiek van het door Van Rietschoten ter discussie gestelde onderwerp in wezen ligt in de vraag wie de verklaring afgeeft het kantoor of de accountant.

Mijn antwoord hierop is, dat de verklaring wordt gegeven door de accountant, daarbij gezag ontlenend o.m. aan de reputatie van zijn kantoor. Op alle aan het kantoor verbonden accountants rust de plicht die reputatie in stand te houden. Zouden de beroepsvoorschriften te dien aanzien geen bepalingen bevatten dan zou hun eigenbelang hen die plicht wel indachtig doen zijn. 